\title{
Design and Implementation of Thermal Body System Employing Thermal Sensor MLX 90614 for Covid-19 Symptoms Early Detector
}

\author{
Puput W. Rusimamto ${ }^{1, *}$ Rina Harimurti ${ }^{2,}$ Endryansyah $^{1,}$ Yeni Anistyasari ${ }^{2,}$ Lilik
}

\author{
Anifah $^{1}$
}

\begin{abstract}
${ }^{1}$ Department of Electrical Engineering, Universitas Negeri Surabaya, Surabaya 60213, Indonesia
${ }^{2}$ Department of Informatic Engineering, Universitas Negeri Surabaya, Surabaya 60213, Indonesia *Corresponding author. Email: puputwanarti@unesa.ac.id
\end{abstract}

\begin{abstract}
Researchers designed and implementation of thermal body measurement system for Unesa residents when they entered the building. The system design is made using engineering methods. Before body temperature is measured, the object will occupy a position at a predetermined point. At that point installed LDR which functions to turn on the servo motor that will move down and turn on the infrared sensor. At an altitude that has been detected by an infrared sensor, the motor will stop and start the temperature measurement process. The temperature sensor uses MLX 90614 which reads data from the reflection of infrared light in the form of raw data. Then the data is processed by a microcontroller using Arduino to become real data. The processed temperature data is displayed by the LCD and sent to the esp32-cam camera. Then esp32-cam will take photos as documentation. Data that has been processed will be grouped according to the 'condition' group that has been determined. Data that has been obtained in the form of temperature data, condition data and photo documentation, is sent to the webserver for display. All temperature measuring components have shown accurate data with the following test results. Sensor Temperature sensor MLX 90614 can measure temperatures at a distance of $30 \mathrm{~cm}$. The temperature measurement program code on Arduino works well with a temperature value of $37.30 \mathrm{C}$. Camera image output format esp32-cam is a JPEG that is displayed on the websever. The Body Temperature Measurement System using the MLX 90614 Temperature Sensor for Early Detection of COVID-19 Symptoms can be used with an average error of $0.6 \%$ and a standard deviation of 0.078 .
\end{abstract}

Keywords: Design, Body temperature measurement system, MLX 90614 temperature sensor, Arduino

\section{INTRODUCTION}

Coronavirus disease (COVID-19) is caused by SARS-COV2 and is a causative agent of a fatal disease of great global public health concern. Based on the large number of infected people exposed to a wet animal market in Wuhan City, China, it is suspected that this is likely the zoonotic origin of COVID-19. Person-toperson transmission of COVID-19 infection results in isolation of patients providing various treatments. Extensive measures to reduce person-to-person transmission of COVID-19 have been implemented to control the current outbreak [1]. Since its identification in late December, this new type of corona virus has infected 92,8600 people and killed 3,162 people as of Wednesday (4/3/2020). Patients who reportedly recovered also experienced a significant increase to 48,252 people. Currently, early detection of the corona virus is often done by checking a person's body temperature. Body temperature is defined as one of the vital signs that describes a person's health status [2]. If a person's body temperature is above normal, it is said that the person has a fever. Fever is a body temperature above normal (> $37.1^{\circ} \mathrm{C}$ ), can be caused by abnormalities in the brain itself or by toxic substances that affect the body's temperature regulation center. The causes of fever include bacterial diseases, brain tumors, and environmental conditions that can end in heat stroke [3].

A number of public facilities such as airports, offices to palaces carry out procedures to check a person's body 
temperature to prevent the spread of the corona virus. Reporting from the South China Morning Post (SCMP), one of the efforts to find out and prevent the spread of the corona virus is by checking the temperature which is equipped with a handheld infrared thermometer or known as a "firing thermometer". The thermometer is used by officers to check people without having to make direct contact [4].

One sign of contracting the corona virus is fever. Humans can be said to have a fever when their body temperature has passed the normal average body temperature, which is 37.1 degrees. This requires early detection of human body temperature. Handheld infrared thermometers have emerged as a popular device for screening people with fever during the coronavirus outbreak. This infrared thermometer is also called a firing thermometer (thermogun) because it looks like a gun that is fired at the forehead. No more than one second, body temperature can be detected immediately. This thermometer can quickly measure surface temperature without touching human skin [4]. Meanwhile, the results of other studies suggest that thermal infrared cameras are a potential reference temperature " fixed point " that can replace mercury thermometers [5].

In line with Roland's idea that the Coronavirus is placing enormous pressure on health care systems worldwide, health analysts, then policy must respond by initiating research on the consequences of current policies [6]. Various attempts have been made by many researchers to detect Covid 19. Among them is Tianxing by carrying out detection tests for nucleic acids and antibodies which play an important role in the rapid identification and isolation of COVID-19 patients to reduce the spread of SARS-CoV-2 infection further [7]. In addition, efforts were also carried out to activate the SARS-CoV-2 RNA virus detection LAMP [8]. Meanwhile, Unesa's efforts in dealing with the COVID19 pandemic include issuing a circular on Anticipatory Measures to Prevent the Spread of COVID-19 in the State University of Surabaya on March 20, 2020. In this circular, Unesa's academics are urged to carry out the flow of health checks and follow Unesa health team protocol directions. Some efforts that can be done are washing hands with soap and water or using the hand sanitizer provided, wearing a mask according to standards and checking body temperature by the relevant officer [9].

In measuring human body temperature for early detection of COVID-19 prevention by using a thermogun, the operation still requires officers to fire at the object's forehead. The officer using the thermo gun must stand as close to the object as possible. And this can endanger officers if the detected object is positive for COVID-19. For this reason, research will be carried out by developing an effective and efficient thermogun for early detection of COVID-19.

\section{METHOD}

The indicator of achievement in this research is the manufacture of a thermogun device for effective and efficient early detection of COVID-19. Effective indicators are reviewed from the performance of the tools developed in measuring temperature accurately. This can be done by calibrating the tool, by comparing measurements manually [10]. Efficient indicators in terms of the use of resources needed in the temperature measurement process. Success indicators can be seen from the achievement of all research targets. Similar research was conducted by Mazgaoker by evaluating the accuracy of temperature measurements using The "Dräger" Double Sensor (DS) [11].

The stages of the research carried out are as follows. The first is to make the PCB layout in accordance with the circuit and continue to install the components according to the component layout on the PCB. Then the power supply is installed, to measure the voltage on each circuit line and the installation of the supporting modules. After completion, proceed with programming the microcontroller components and installation of the circuit along with the module to the tool frame. The next step is to test the tool and the tool calibration process.

\subsection{Design}

The design of the tool to be developed is shown in Figure 1. From this design, a system block diagram is made which is shown in Figure 2, Figure 3 and Figure 4.

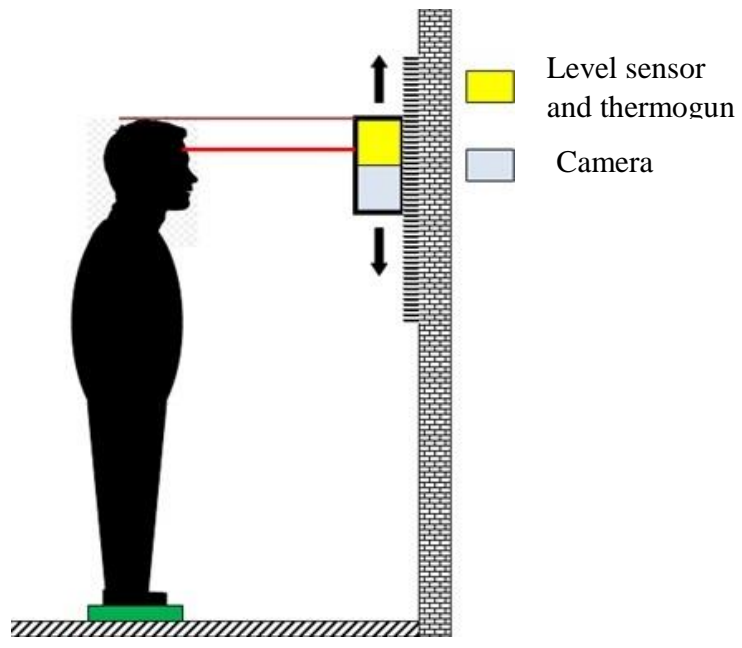

Figure 1 Thermogun Development Design 


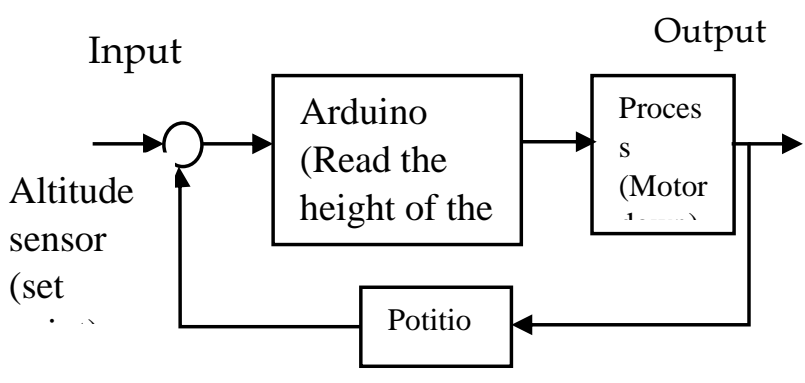

Figure 2 Block diagram of the position program (Loop I)

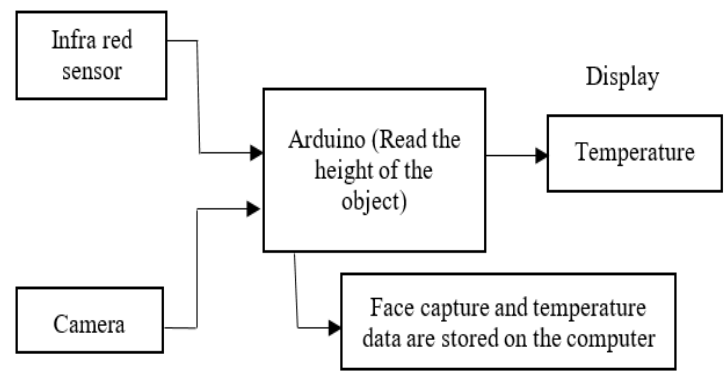

Figure 3 Block diagram of the measurement program (Loop II)

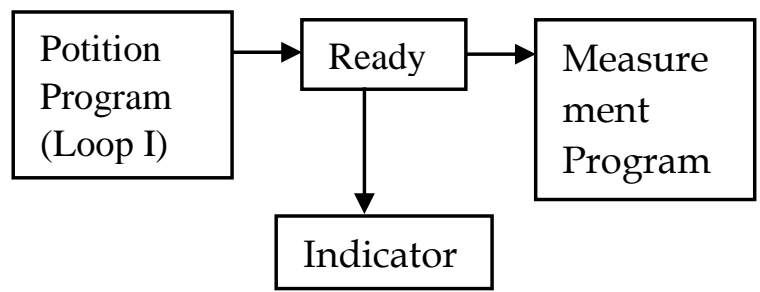

Figure 4 Program step block diagram

How the tool works is described as follows. When power on, the tool will condition itself to the initial set state. Namely where the measuring box is at the very top and connects wifi according to the settings used. When the sensor detects a user, the gauge box will drop to adjust the user's head using an infrared sensor in the gauge box, shown in Figure 2. If the sensor has detected the user's head, the microcontroller will read the user's head temperature. At the same time, the system will trigger the camera to take a picture. Then the temperature sensor readings will appear, at that time the photo data and temperature data are sent to the web page on the localhost of the tool, as shown in Figure 3.If the temperature reads $380 \mathrm{C}$, the buzzer will light up as a sign that the user's temperature exceeds boundaries that are set and are in the early detection category of COVID-19. The user can leave the position when the camera flash has flashed, as a sign that all readings from temperature and photo are complete. If the user detection sensor does not read the presence of a user, the gauge box will return to the top, to the starting position.
All recorded data will be stored in a database on the computer. Overall the measurements of loops I and II are simplified in Figure 4.

\section{RESULT AND DISCUSSION}

Based on the system design that has been discussed previously, the next step is making tools. The microcontroller used is the Arduino Pro mini Atmega328p - 8 BIT AVR controller and the camera used is the Esp32 Cam WiFi + BT Soc Module, as shown in Figure 5. The temperature sensor used is MLX90614-ACF. This sensor works by absorbing infrared light emitted by an object. Since this sensor is not in physical contact with the object being measured, it has a wide measurement range from $-70^{\circ} \mathrm{C}$ to $+380^{\circ}$ C. To detect objects or obstacles with a certain distance using the E18-D80NK IR Obstacle Avoidance Proximity with the infrared light reflection method which has excellent accuracy and response. The distance can be adjusted from $3 \mathrm{~cm}$ to $80 \mathrm{~cm}$. The advantage of this sensor is that its design is made for real use, and is not affected by indirect light from the sun. To adjust the speed and direction of the DC motor using the L298N Motor Driver. The servo motor used is a highperformance MG995 with metal gears, double ball bearings, $180{ }^{\circ}$ rotation, $30 \mathrm{~cm}$ long connection cable, and is equipped with accessories to use as needed. This servo motor is suitable for applications requiring a motor with sufficient torque up to $13 \mathrm{~kg} . \mathrm{cm}$ (stall torque limit at 7.2 Volts).

The next step is programming the microcontroller as shown in Figure 6. It is the integration between software and hardware. After the software and hardware manufacturing process is complete, the results of the research are tested in the rectorate building as shown in Figure 7 and Figure 8. All temperature measurement results and camera photos are integrated into a web page on the localhost of the tool as shown in Figure 9. Then conducted trials as well as calibrating the tool. The results are shown in Table 1.The calculation of the average error from the measurement of the research results on the thermogun is shown in Table 2. While the statistical data of the research results are shown in Table 3. 


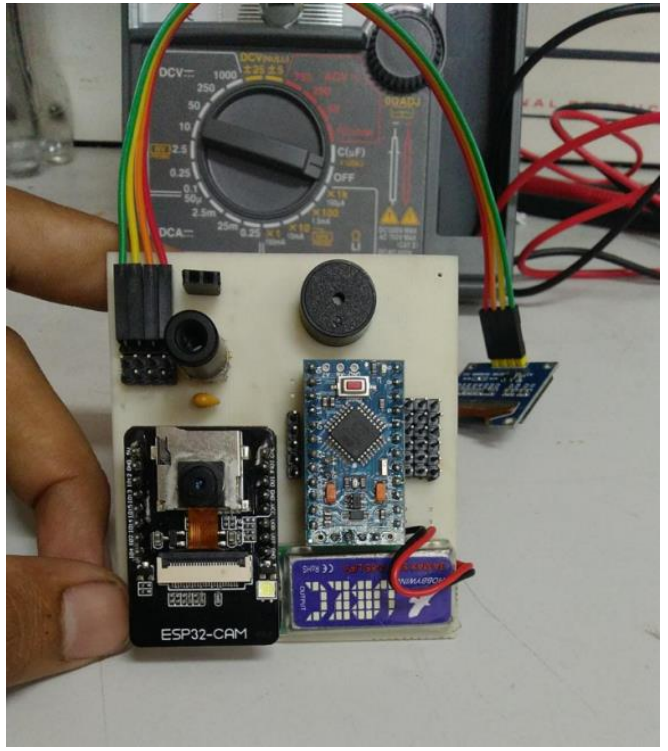

Figure 5 The camera hardware used by the ESP32-CAM

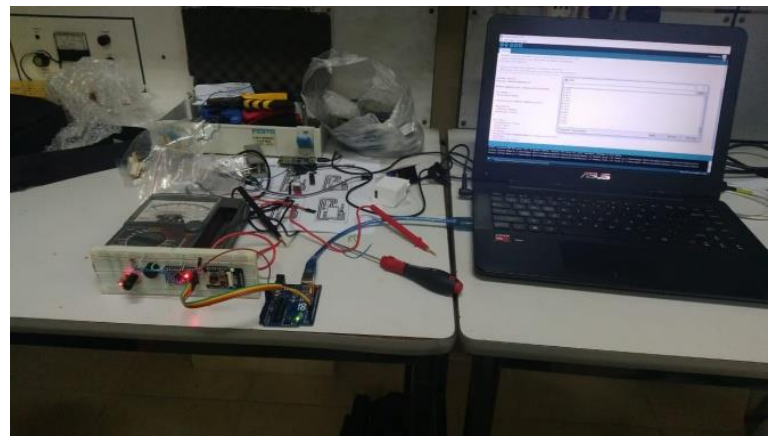

Figure 6 The integration process between software and hardware

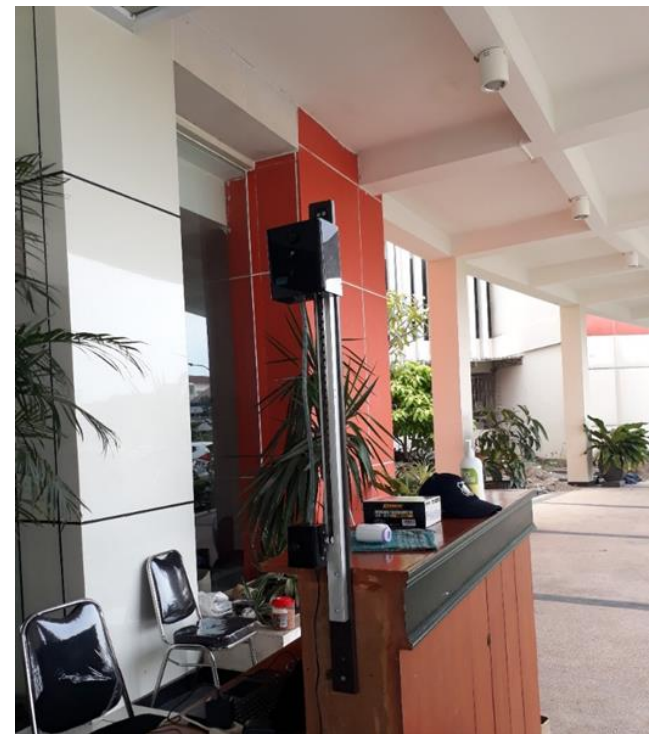

Figure 7 Complete view of temperature detection system

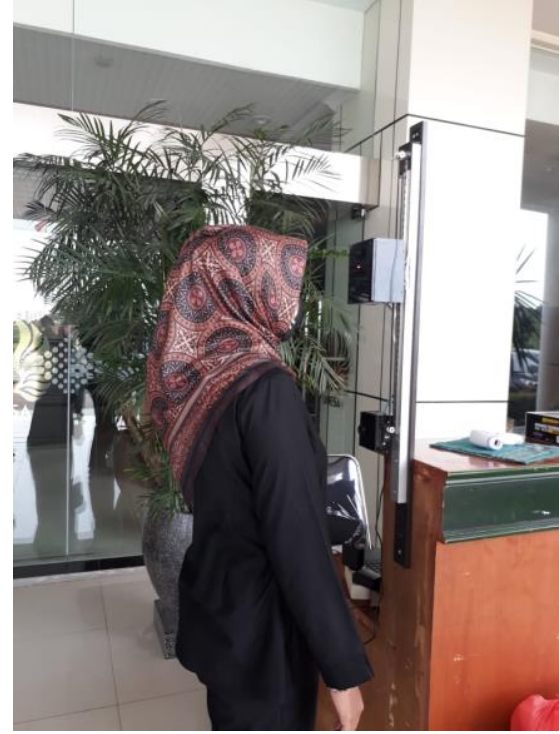

Figure 8 Testing process

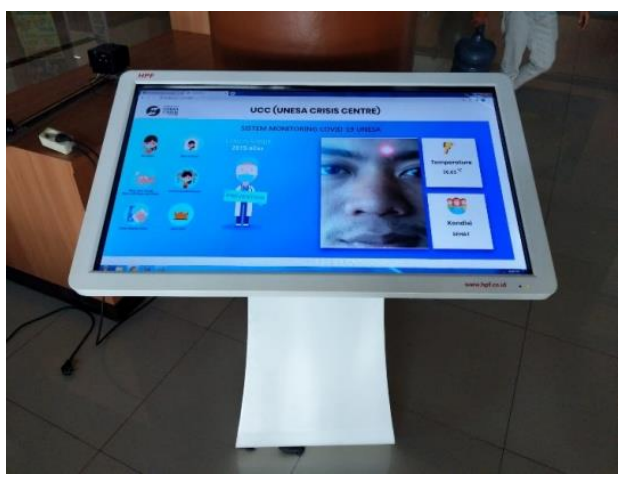

Figure 9 Display on the display

Table 1. The test results of the temperature detection system

\begin{tabular}{|c|l|c|c|c|c|c|c|c|c|c|c|}
\hline \multirow{2}{*}{ No. } & \multirow{2}{*}{ Measurement } & \multicolumn{10}{|c|}{ Measurement Result } \\
\cline { 2 - 12 } & $\mathbf{1}$ & $\mathbf{2}$ & $\mathbf{3}$ & $\mathbf{4}$ & $\mathbf{5}$ & $\mathbf{6}$ & $\mathbf{7}$ & $\mathbf{8}$ & $\mathbf{9}$ & $\mathbf{1 0}$ \\
\hline $\mathbf{1}$ & $\begin{array}{l}\text { Temperature } \\
\text { Thermogun } \\
\left({ }^{\circ} \mathrm{C}\right)\end{array}$ & 36 & 36 & 36 & 35,9 & 36,1 & 36,1 & 36,1 & 35,9 & 35,9 & 35,9 \\
\hline 2 & $\begin{array}{l}\text { Temperature } \\
\text { Research Tool } \\
\left({ }^{\circ} \mathrm{C}\right)\end{array}$ & 35,9 & 35,9 & 36 & 36 & 35,92 & 36,12 & 36,12 & 36 & 36 & 36 \\
\hline 3 & $\begin{array}{l}\text { Temperature } \\
\text { Sensor (V) }\end{array}$ & 3,3 & 3,3 & 3,3 & 3,3 & 3,3 & 3,3 & 3,3 & 3,3 & 3,3 & 3,3 \\
\hline 4 & $\begin{array}{l}\text { Infrared } \\
\text { Sensor (V) }\end{array}$ & 5 & 5 & 5 & 5 & 5 & 5 & 5 & 5 & 5 & 5 \\
\hline 5 & Camera (V) & 3,3 & 3,3 & 3,3 & 3,3 & 3,3 & 3,3 & 3,3 & 3,3 & 3,3 & 3,3 \\
\hline 6 & Laser (V) & 5 & 5 & 5 & 5 & 5 & 5 & 5 & 5 & 5 & 5 \\
\hline 7 & Buzzer (V) & 5 & 5 & 5 & 5 & 5 & 5 & 5 & 5 & 5 & 5 \\
\hline 8 & LCD (V) & 3,3 & 3,3 & 3,3 & 3,3 & 3,3 & 3,3 & 3,3 & 3,3 & 3,3 & 3,3 \\
\hline 9 & Servo (V) & 12 & 12 & 12 & 12 & 12 & 12 & 12 & 12 & 12 & 12 \\
\hline
\end{tabular}


Table 2. Calculation of the average error in temperature measurements

\begin{tabular}{|c|c|c|l|}
\hline $\begin{array}{c}\text { Measure- } \\
\text { ment to }\end{array}$ & $\begin{array}{c}\text { Temperature } \\
\text { Thermogun }\end{array}$ & $\begin{array}{c}\text { Temperature } \\
\text { Research Tool }\end{array}$ & Error \\
\hline 1 & 36 & 35.9 & 0.1 \\
\hline 2 & 36 & 35.9 & 0.1 \\
\hline 3 & 36 & 36 & 0 \\
\hline 4 & 35.9 & 36 & -0.1 \\
\hline 5 & 36.1 & 35.92 & 0.18 \\
\hline 6 & 36.1 & 36.12 & -0.02 \\
\hline 7 & 36.1 & 36.12 & -0.02 \\
\hline 8 & 35.9 & 36 & -0.1 \\
\hline 9 & 35.9 & 36 & -0.1 \\
\hline 10 & 35.9 & 36 & -0.1 \\
\hline Average & 35.99 & 35.996 & -0.006 \\
\hline
\end{tabular}

Table 3. Research data statistics

\begin{tabular}{|c|r|r|}
\hline & \multicolumn{1}{|c|}{ Thermogun } & Research result \\
\hline \multirow{2}{*}{$\begin{array}{c}\text { V Valid } \\
\text { Missing }\end{array}$} & 10 & 10 \\
\cline { 2 - 3 } & 0 & 0 \\
\hline Mean & 35.9900 & 35.9960 \\
\hline Median & 36.0000 & 36.0000 \\
\hline Mode & 35.90 & 36.00 \\
\hline Std. & .08756 & .07820 \\
Deviation & & .006 \\
\hline Variance & .008 & .22 \\
\hline Range & 35.90 & 35.90 \\
\hline Minimum & 36.10 & 36.12 \\
\hline Maximum & 359.90 & 359.96 \\
\hline Sum & & \\
\hline \multicolumn{2}{|c|}{ Sur| }
\end{tabular}

The result of the calculation of the average error is $0.6 \%$, with the standard deviation of measurement using the thermogun of 0.088 and the standard deviation of measurement using the research results is 0.078 .

\section{CONCLUSION}

From the results of the research and discussion, it was concluded that the Body Temperature Measurement System using the MLX 90614 Temperature Sensor for Early Detection of COVID-19 Symptoms can be used with an average error of $0.6 \%$ and a standard deviation of 0.078 .

\section{ACKNOWLEDGMENTS}

This research was supported by the State University of Surabaya.

\section{REFERENCES}

[1] H. A. Rothan and S. N. Byrareddy, "The epidemiology and pathogenesis of coronavirus disease ( COVID-19 ) outbreak," J. Autoimmun., no. February, p. 102433, 2020.

[2] Y. Kukus et al., "Suhu tubuh: homeostasis dan efek terhadap kinerja tubuh manusia," $J$. Biomedik, vol. 1, no. 2, pp. 107-118, 2009.

[3] L. Sherwood, Fisiologl Manusia. Buku Kedokteran EGC, 2012.

[4] R. K. Dewi and S. Hardiyanto, "Pencegahan Virus Corona , Deteksi Suhu dan Penggunaan Termometer Tembak ...," 2020. [Online]. Available:

https://www.kompas.com/tren/read/2020/03/04/ 091611465/pencegahan-virus-corona-deteksisuhu-dan-penggunaan-termometer-tembak. [Accessed: 04-Apr-2020].

[5] R. Y. Kannan et al., "Infrared cameras are potential traceable ' fixed points' for future thermometry studies Infrared cameras are potential traceable "“ fixed points "” for future thermometry studies," vol. 1902, no. October, pp. 1-6, 2015.

[6] R. Bal, B. De Graaff, H. Van De Bovenkamp, and I. Wallenburg, "Practicing Corona Towards a research agenda of health policies," Health Policy (New. York)., vol. 124, no. 7, pp. 671-673, 2020.

[7] T. Ji et al., "Biosensors and Bioelectronics Detection of COVID-19: A review of the current literature and future perspectives," Biosens. Bioelectron., vol. 166, no. March, p. 112455, 2020.

[8] D. Thompson and Y. Lei, "Mini review : Recent progress in RT-LAMP enabled COVID-19 detection," Sensors and Actuators Reports, vol. 2, no. 1, p. 100017, 2020.

[9] H. Unesa, "Tindakan Antisipasi , Unesa Keluarkan Surat Edaran Pencegahan Penyebaran Covid-19," 2020. [Online]. Available: https://www.unesa.ac.id/tindakanantisipasi--unesa-keluarkan-surat-edaranpencegahan-penyebaran-covid-19. [Accessed: 04-Apr-2020].

[10] E. O. Doebelin, Hasto, E. Aritonang, and Suwarso, Sistem Pengukuran Aplikasi dan Perancangan. Jakarta: Erlangga, 1987.

[11] S. Mazgaoker, I. Ketko, R. Yanovich, Y. Heled, and Y. Epstein, "Measuring core body temperature with a non-invasive sensor," $J$. Therm. Biol., vol. 66, no. March, pp. 17-20, 2017. 